\title{
Membangun Customer Relationship Management Pada Konsumen Sepeda Motor Honda ( Studi Pada Konsumen SkuterMatic, Honda di Sukoharjo )
}

\author{
Linda Nur Susila*, Setyani Sri Haryanti* \\ STIE Adi Unggul Bhirawa Surakarta \\ Email : lindaencis@gmail.com ${ }^{1}$, setyani_pemnas@ymail.com ${ }^{2}$ \\ 2019
}

\begin{abstract}
Abstrak
Tujuan Penelitian ini untuk mengetahui secara empiris Membangun Customer Relationship management Pada Konsumen Sepeda Motor Honda (Studi Pada Konsumen Skuter Matic, Honda di Sukoharjo ). Data yang digunakan adalah data primer, sedangkan tehnik pengambilan dengan kuestioner yang diberikan kepada konsumen sepeda motor Skuter Matic Honda di dealer Honda Grogol Sukoharjo, sebanyak 88 orang sebagai sampel. Teknik analisis data dalam penelitian ini menggunakan model Regresi intervening. Hasil uji instrumen menunjukkan semua valid dan reliabel. Dari hasil uji t : Kualitas produk berpengaruh positif dan signifikan terhadap citra merek. Customer relationship management berpengaruh positif dan signifikan terhadap citra merek. Kualitas produk berpengaruh positif dan signifikan terhadap keputusan membeli. Customer relationship management berpengaruh positif dan signifikan terhadap keputusan membeli. Citra Merek berpengaruh positif dan signifikan terhadap keputusan membeli. Hasil uji secara serempak (Uji F) pada persamaan kedua diketahui besarnya nilai $\mathrm{F}=22,232$ signifikansi $0,000<0,05$. Sehingga dapat disimpulkan secara bersama-sama variable bebas berpengaruh signifikan terhadap keputusan membeli. Nilai determinasi total sebesar 0341, berarti variasi keputusan membeli dijelaskan oleh kualitas produk dan customer relationship management dengan citra merek sebagai variable intervening sebesar $34,1 \%$, sisanya $65,9 \%$ dijelaskan variabel di luar model, misalnya harga dan lokasi. Koefisien jalur langsung pengaruh kualitas produk dan customer relationship management terhadap keputusan membeli lebih besar dari pada jalur tidak langsung, sehingga Citra merek tidak efektif sebagai variabel mediasi. Customer relationship management lebih efektif dalam meningkatkan keputusan membeli.
\end{abstract}

Kata kunci :kualitas produk, customer relationship management, citra merek dan keputusan membeli.

\begin{abstract}
CUSTOMER RELATIONSHIP MANAGEMENT BUILDING AT CONSUMER OF MOTORBIKE HONDA (Study At Consumer Skutermatic, Honda in Sukoharjo). This research target to know and give the empirical evidence of Customer Relationship Growth Management at Consumer of Motorbike Honda ( Study At Consumer Skutermatic, Honda in Sukoharjo ). Data used is primary data taken with the questionnaire which pased of consumer of bicycle motor SkuterMatic, Honda in dealer Honda Grogol Sukoharjo, as much 88 people as sampel. Technique appliance analyse the data in this research will use the model of Regresi intervening . Result of instrument test show the valid data and reliable. Result of test $t$ : quality of product of have an effect on positive and signifikan as brand image. Customer relationship management, Product quality of have an effect on positive and signifikan as purchasing decesion. Customer relationship management. brand image have an effect on positive and signifikan as purchasing decesion. Total coefficient determinasi equal to 0,341 , is meaning variation explainable purchasing decesion of quality product and customer relationship management with brand image as intervening variable equal to $34,1 \%$, and remains $65,9 \%$ explained by other; dissimilar variable outside model, for example price and location. Direct band that is influence of product quality and bigger customer relationship management of purchasing decesion than band do not direct. Brand image is not effective as variable mediasi. Customer Relationship management more effective in improving purchasing decision.
\end{abstract}

Keyword : product quality, customer relationship management, brand image, purchasing decision.. 


\section{Pendahuluan}

Era globalisasi saat ini banyak produsen barang dari perusahaan saling bersaing dalam memasarkan produk mereka untuk menarik minat konsumen. Perusahaan harus berusaha menciptakan dan mempertahankan konsumen untuk meraih kesuksesan dalam dunia bisnis. Tujuan tersebut dapat tercapai apabila perusahaan selalu berupaya untuk menampilkan produk mereka sesuai dengan apa yang diinginkan konsumen dan mempunyai kualitas produk yang sesuai dengan daya beli calon konsumennya.

Semakin tinggi tingkat mobilitas akan berpengaruh terhadap semakin tingginya pemenuhan alat transportrasi bagi masyarakat. Sepeda motor bagi masyarakat merupakan alat transportrasi yang praktis dan efisien. Melihat tingginya minat masyarakat terhadap sepeda motor hal ini dimanfaatkan oleh para produsen sepeda motor untuk memenuhi kebutuhan transportasi masyarakat, sehingga timbulah persaingan yang sengit antar perusahaan yang bergerak di bidang otomotif.

Berbagai macam varian dan inovasi sepeda motor diluncurkan oleh perusahaan otomotif untuk memenuhi keinginan konsumen. Seperti motor bebek, skuter matic, dan sport. Sepeda motor skuter matic memiliki pasaran yang fantastis. Hal ini dapat dibuktikan melalu banyaknya tipe Sepeda motor skuter matic yang sering terlihat di jalanan kota. Sepeda motor skuter matic banyak diminati karena cara penggunaanya yang mudah yaitu menggunakan mesin dengan transmisi otomatik (sumber: Yuliana, 2015. http://hargamotor.co.id/review- motor/10-sepeda-motormatic-terbaik-di indonesia).

Selain itu sepeda motor jenis skuter matic lebih nyaman digunakan saat berada diperkotaan yang macet karena lebih mudah bermanuver tanpa harus sering mengganti gigi perseneling. Konsep yang dimiliki sepeda motor jenis ini juga digemari kalangan muda khususnya wanita yang lebih menyukai karena adanya frame depan rendah (underbone), serta dilengkapi area pijakan kaki rider yang luas dan berbentuk bidang datar. (Yuliana, 2015. http://hargamotor.co.id/review-motor/10-

sepeda-motor-matic-terbaik-di-indonesia).

Berdasarkan data penjualan sepeda motor matic semester 1 tahun 2015 yang dirilis oleh Asosiasi Industri Sepeda Motor Indonesia (AISI) juni 2015 Honda memperoleh market share sebesar $75,70 \%$ dengan total penjualan 1.841.916 unit. Sedangkan Yamaha memperoleh market share sebesar 23,30\% dengan total penjualan 566.911 unit, kemudian disusul oleh Suzuki dengan market share sebesar 0,94\% dengan total penjualan sebesar

22.984 unit, dan TVS memperoleh market share sebesar 0,05\% dengan total penjualan 1.211 unit. (Ipanse, 2015. http://pertamax7.com/2015/07/15/honda-juara-motor-matic-dan-bebek-ms-66-yamaha- juaranya-motor-sportaisi-semester-1-2015/).

CustomerRelationship management adalah suatu proses menciptakan, mempertahankan dan meningkatkan hubunganhubungan yang kuat dengan para pelanggan dan stakeholder lainnya. Selain merancang strategi baru untuk menarik pelanggan baru dan menciptakan transaksi dengan mereka, perusahaan terus menerus sedang berjuang matimatian untuk mempertahankan pelanggan yang ada dan membangun relasi jangka panjang yang mampu mendatangkan laba. Citra Merek (Brand Image) menurut Aaker (dalam Rangkuti, 2002:36) adalahmempresentasikan keseluruhan merek yang dibentuk dari informasi dan pengalaman masa lalu terhadap merek tersebut.Pengenalan konsumen terhadap merek atau citra terhadap satu merek merupakan hal yang tidak kalah pentingnya dalam melakukan srategi pemasaran. Masyarakat akan cenderung tertarik pada produk dengan citra yang baik serta dikenal luas. Honda mampu menempatkan merek tersebut selalu berada pada pilihan nomor satu di masyarakat.Selain itu merek yang diciptakan oleh sepeda motor Honda selalu mendapat sambutan baik dari konsumen.

Keputusan pembelian merupakan tindakan akhir konsumen dalam memilih produk yang akan mereka gunakan. Setiadi (2010:332) berpendapat bahwa inti dari pengambilan keputusan konsumen (cunsumer decision making) adalah proses pengintegrasian yang mengkombinasikan pengetahuan untuk mengevaluasi dua atau lebih perilaku alternatif, dan memilih salah satu diantaranya.Menurut Setiadi (2010:14) proses pembelian yang spesifik terdiri dari urutan kejadian berikut: pengenalan masalah, pencarian informasi, evaluasi alternatif, keputusan pembelian, dan perilaku pasca-pembelian.

Honda bukanlah perusahaan otomotif yang pertama dalam pasar motor skuter matic. Honda mempunyai persaingan yang ketat dengan para pesaingnya, yang membuat mereka harus tetap mampu berinovasi dan memperbaiki kinerja 
perusahaan. Berdasarkan latar belakang tersebut, maka judul penelitian ini "Membangun Custome Relationship management Pada Konsumen Sepeda Motor Honda (Studi Pada Konsumen Skuter Matic, Honda di Sukoharjo)".

\section{Perumusan Masalah Dan Pembatasan Masalah}

Berdasarkan permasalahan penelitian tersebut maka dimunculkan pertanyaan penelitian sebagai berikut:

1. Apakah kualitas produk berpengaruh sigifikan terhadap citra merek sepeda motor Skuter Matic Honda di Sukoharjo?

2. Apakah customer relationship management berpengaruh sigifikan terhadap citra merk sepeda motor Skuter Matic Honda di Sukoharjo?

3. Apakah kualitas produk berpengaruh sigifikan terhadap keputusan membeli sepeda motor Skuter Matic Honda di Sukoharjo?

4. Apakah customer relationship management berpengaruh sigifikan terhadap keputusan membeli sepeda motor Skuter Matic Honda di Sukoharjo?

5. Apakah citra merk berpengaruh sigifikan terhadap keputusan membeli sepeda motor Skuter Matic Honda di Sukoharjo?

Batasan masalah diperlukan untuk menghindari pembahasan yang terlalu luas, dalam penelitian ini:

1. Objek penelitian dibatasi pada konsumen sepeda motor Skuter Matic Honda di Dealer Honda motor Kecamatan Grogol Kabupaten Sukoharjo.

2. Variabel yang dipakai dalam penelitian yaitu kualitas produk, customer relationship management, citra merek dan keputusan membeli.

\section{Tujuan dan Manfaat Penelitian}

1. Tujuan Penelitian

Tujuan penelitian ini adalah:

a. kualitas produk terhadap citra merek sepeda motor Skuter Matic Honda di Sukoharjo.

b. Mengetahui secara empiris pengaruh customer relationship management terhadap citra merek sepeda motor Skuter Matic Honda di Sukoharjo.

c. Mengetahui secara empiris pengaruh kualitas produk terhadap keputusan membeli sepeda motor Skuter Matic Honda di Sukoharjo.

d. Mengetahui secara empiris pengaruh customer relationship management terhadap keputusan membeli sepeda motor Skuter Matic Honda di Sukoharjo.

e. Mengetahui secara empiris pengaruh citra merk terhadap keputusan membeli sepeda motor Skuter Matic Honda di Sukoharjo.

2. Manfaat Penelitian

Manfaat penelitian ini adalah sebagai berikut:

a. Bagi Dealer Honda Grogol Sukoharjo Penelitian ini diharapkan dapat menjadi bahan pertimbangan pihak manajemen dalam pengambilan keputusan strategi penjualan sepeda motor Skuter Matic Honda.

b. Bagi Akademik

Hasil penelitian ini diharapkan mampu menjadi refrensi dan dapat memberikan kontribusi pada pengembangan studi mengenai pemasaran maupun penelitian berikutnya.

\section{Landasan Teori}

\section{Pemasaran}

Menurut Stanton (2005:15) pemasaran adalah suatu sistem keseluruhan dari kegiatan bisnis yang itujukan untuk merencanakan, menentukan harga, mempromosikan, dan mendistribusikan barang atau jasa yang memuaskan kebutuhan baik kepada pembeli yang ada maupun pembeli potensial. 
Pemasaran merupakansuatu kegiatan pertemuan yang dilakukan oleh suatu individu atau kelompok untuk melakukan pertukaran barang atau jasa dalam rangka memenuhi kebutuhan maupun keinginan. Pemasaran merupakan sistem kegiatan yang saling berhubungan yang ditujukan untuk kegiatan menciptakan, menentukan harga, mempromosikan, dan mendistribusikan barang atau jasa kepada para konsumen.

Kotler (2005:10) berpendapat bahwa pemasaran merupakan proses sosial yangdengan proses tersebut individu dan kelompok mendapatkan apa yang mereka butuhkan dan inginkan dengan menciptakan, menawarkan, dan secara bebas mempertukarkan produk dan jasa yang bernilai terhadap pihak lain.

2. Perilaku Konsumen

Perilaku konsumen adalah kegiatan- kegiatan individu yang secara langsung terlibat dalam mendapatkan dan mempergunakan barang dan jasa tersebut didalamnya proses pengambilan keputusan pada persiapan dan penentuan kegiatan- kegiatan tersebut. (Swasta dan Handoko, 2000:10).

Perilaku konsumen adalah suatu tindakan yang dilakukan oleh individu, kelompok atau organisasi yang berhubungan dengan pengambilan keputusan dalam mendapatkan, menggunakan barang dan jasa secara ekonomis yang dapat dipengaruhi lingkungannya, mahal atau sulit untuk beralih kepada penyelia layanan yang lain.

3. Keputusan Pembelian

Kotler (2005:204) mengemukakan bahwa dalam proses pembelian terdapat lima tahapan yang akan dilalui yaitu pengenalan masalah, pencarian, informasi, evaluasi alternative, keputusan pembelian, dan perilaku paska pembelian. Setiap konsumen akan melelui ke lima tahap tersebut, namun proses yang dilalui tidaklah sama dan saling berurutan.

Perilaku paska pembelian merupakan faktor penentu bagi pemasar, karena puas atau ketidakpuasan konsumen akan mempengaruhi tingkah laku selanjutnya. Konsumen yang merasa tidak puas dan merasa pengorbanan yang dilakukan tidak sepadan dengan manfaat yang ada dalam produk, akan melakukan penghentian pemakaian produk. Begitupun sebaliknya apabila mereka merasa puas maka kunsumen akan melakukan pembelian ulang.

\section{Kualitas Produk}

Kualitas suatu produk atau jasa ditentukan oleh para pelanggan.Perusahaan atau organisasi akan mengetahui dan menyetujui apa yang diinginkan dan dibutuhkan oleh pelanggan, kemudian perusahaan atau organisiasi tersebut harus menghasilkan produk yang tepat dengan apa yang dibutuhkan dan diinginkan konsumen. Sehingga produk yang mereka hasilkan dapat selalu menarik bagi konsumen.

Menurut Kotler \& Keller (2009:9) kualitas produk merupakan keseluruhan ciri serta sifat barang dan jasa yang berpengaruh pada kemampuan memenuhi kebutuhan yang dinyatakan maupun secara tersirat.Sedangkan Tjiptono (2008:106) berpendapat Kualitas merupakan perpaduan antara sifat dan karakteristik sebuah produk, dan menilai seberapa jauh sifat dan karakteristik tersebut dapat memenuhi kebutuhannya.

\section{Customer Relationship Management}

Relationship management adalah suatu proses menciptakan, mempertahankan dan meningkatkan hubunganhubungan yang kuat dengan para pelanggan dan stakeholder lainnya. Selain merancang strategi baru untuk menarik pelanggan baru dan menciptakan transaksi dengan mereka, perusahaan terus menerus sedang berjuang matimatian untuk mempertahankan pelanggan yang ada dan membangun relasi jangka panjang yang mampu mendatangkan laba dengan mereka. (Kotler dan Amstrong,2004:789).

Menurut Bonne dan Kurtz (2006:140), relationship management adalah suatu pengembangan dan pemeliharaan dalam jangka panjang untuk hubungan biaya yang efektif dengan pelanggan secara individu, pemasok, karyawan, dan untuk kerjasama lain yang saling menguntungkan.

\section{Citra Merek (Brand Image)}

Pengertian merek menurut Kotler (2000:443) adalah nama, istilah, tanda, simbol, atau desain atau kombinasi dari semuanya yang dimaksudkan untuk mengidentifikasikan barang dan jasa darinya. Perusahaan dalam menciptakan produk akan kepribadian yang tercermin dari merek tersebut. Merek menggambarkan nilai yang akan ditawarkan dan memeiliki peranan yang penting dalam menetapkan pilihannya. Persaingan merek 
begitu dominan, maka merek dianggap sebagai asset berharga di dalam perusahaan.Merek menjadi sangat penting bagi perusahaan karena beberapa faktor.

Kotler et al. (2000: 770) mendefinisikan Citra merek (brand image) yaitu sejumlah kepercayaan yang dipegang oleh konsumen berkataitan dengan merek. Sedangkan Kotler dan Amstrong (2001:225) Citra merek adalah seperangkat keyakinan konsumen mengenai merek tertentu.

Citra merek (brand image) dengan Brand Association saling berkaitan satu sama lain. Asosiasi merek (brand association) menurut Aaker dalam Tjiptono (2005:40) adalah segala sesuatu yang terkait dengan memori terhadap sebuah merek. Asosiasi yang terjalin pada suatu merek dapat membentuk citra merek.Setiap pelanggan akan memiliki kesan tertentu pada merek suatu produk. Kesan tersebut timbul setelah calon pelanggan melihat, mendengar, membaca atau merasakan sendiri merek produk, baik melalui televisi, radio, maupun media cetak.

\section{PENELITIAN TERDAHULU}

Nela Evelina, Handoyo DW, Sari Lestyorini (2012). Pengaruh citra merek, kualitas produk, harga, dan promosi terhadap keputusan pembelian kartu perdana Telkomfexi.

Rahmad Rispandi Sinaga (2012). Analisis Pengaruh Customer Relationship Marketing dan Layanan Purna Jual Terhadap Penjualan pada CV.Bamex Engeenring. Batam.

\section{KERANGKA KONSEPTUAL}

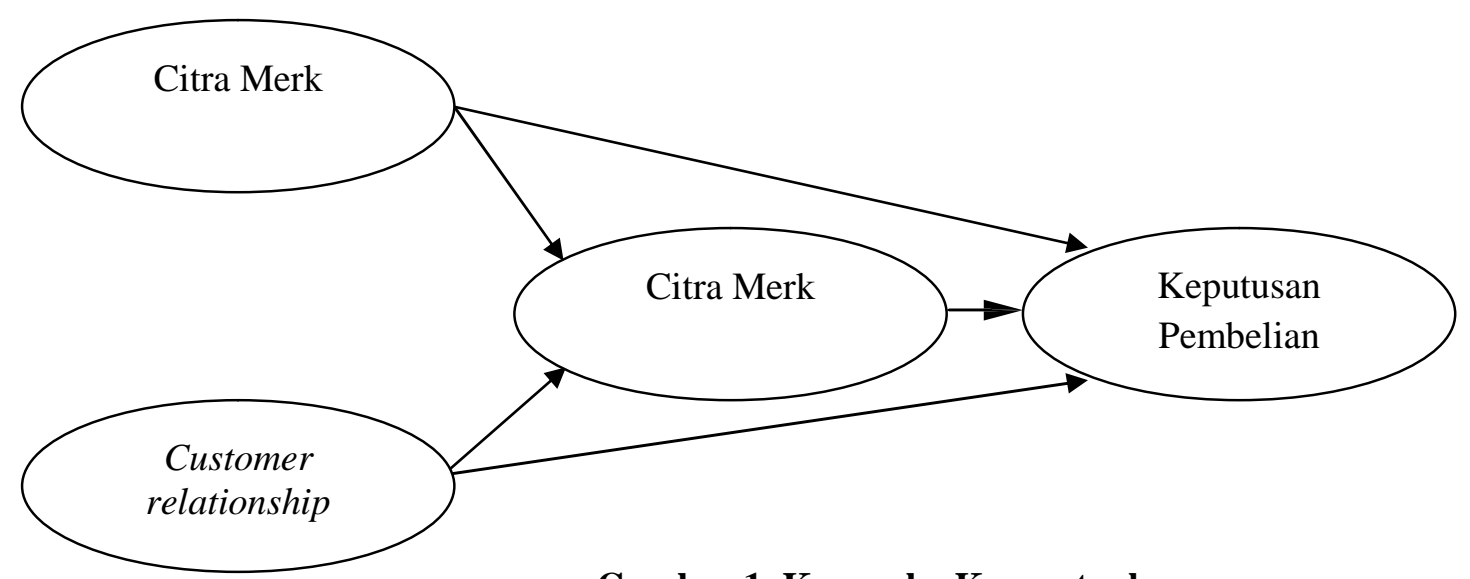

\section{Gambar 1. Kerangka Konseptual}

Sumber : Evelina (2012), Prasetyo (2012), Santosa (2013), Afred

\section{HIPOTESIS PENELITIAN}

$\mathrm{H}_{1}$ : Kualitas Produk berpengaruh signifikan terhadap citra merek sepeda motor Skuter matic Honda diDealer Honda Grogol Kabupaten Sukoharjo.

$\mathrm{H}_{2}$ : Customer relationship management berpengaruh signifikan terhadap citra merek sepeda motor Skuter matic HondadiDealer Honda Grogol Kabupaten Sukoharjo.

$\mathrm{H}_{3}$ : Kualitas produk berpengaruh signifikan terhadap keputusan pembelian sepeda motor Skuter matic Honda di Dealer Honda Grogol Kabupaten Sukoharjo.

$\mathrm{H}_{4}$ : Customer relationship management berpengaruh signifikan terhadap keputusan pembelian sepeda motor Skuter matic HondadiDealer Honda $\mathrm{H} 5$

$\mathrm{H}_{5}$ : Citra Merek berpengaruh signifikan terhadap keputusan pembelian sepeda motor Skuter matic Honda di Dealer Honda Grogol Kabupaten Sukoharjo. 


\section{METODOLOGI PENELITIAN}

Data yang digunakan dalam penelitian ini adalah data primer yang diambil dengan daftar pertanyaan yang diberikan kepada konsumen sepeda motor SkuterMatic, Honda di dealer Honda Grogol Sukoharjo, sebanyak 88 orang sebagai sampel.

Alat teknik analisis data dalam penelitian ini akan menggunakan model Regresi intervening.

Analisis regresi linear berganda digunakan untuk menganalisa pengaruh beberapa variabel bebas atau independen variabel (X) terhadap satu variabel tidak bebas atau dependen variabel (Y) sebagai berikut:.

Persamaan 1: $Y_{1}=\beta_{1} X_{1}+\beta_{2} X_{2}+\varepsilon$

Persamaan 2: $Y_{2}=\beta_{1} X_{1}+\beta_{2} X_{2}+\beta_{3} X_{3}+\varepsilon$

\section{HASIL PENELITIAN}

Analisis Jalur

1. Hasil Uji Regresi Persamaan 1

Coefflolets

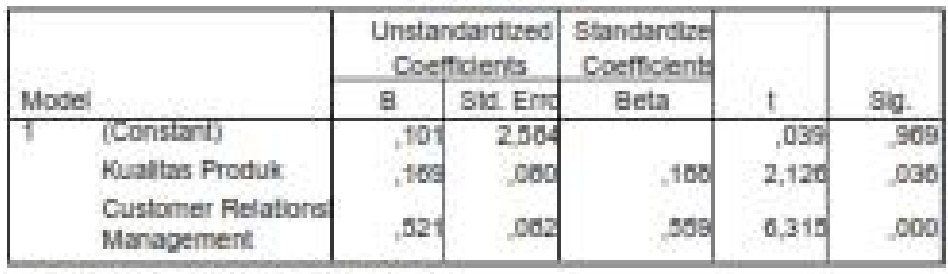

a. Deperident Variable: Cira Merek

\section{Hasil Uji Regresi Persamaan 2}

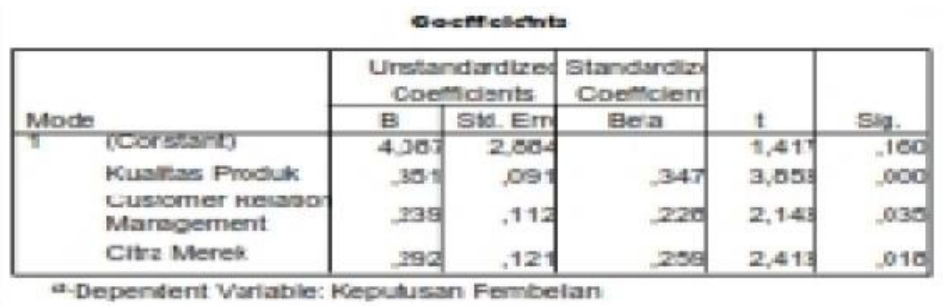

\section{Penjelasan hasil regresi:}

a. $\mathrm{b}_{1}$ sebesar 0,188 artinya Kualitas Produk berpengaruh positif terhadap citra merek sepeda motor Skuter Matic Honda di Dealer Honda Grogol Kabupaten Sukoharjo.

b. $\mathrm{b}_{2}$ sebesar 0,559 artinya Customer relationship management berpengaruh positif terhadap citra merek sepeda motor Skuter Matic Honda di Dealer Honda Grogol Kabupaten Sukoharjo.

c. $b_{3}$ sebesar 0,347 artinya Kualitas produk berpengaruh positif terhadap keputusan membeli sepeda motor Skuter Matic Honda di Dealer Honda Grogol Kabupaten Sukoharjo.

d. $\mathrm{b}_{4}$ sebesar 0,228 artinya Customer relationship management berpengaruh positif terhadap keputusan membeli sepeda motor Skuter Matic Honda di Dealer Honda Grogol Kabupaten Sukoharjo.

e. $b_{5}$ sebesar 0,259 artinya Citra Merek berpengaruh positif terhadap keputusan membeli sepeda motor Skuter matic Honda di Dealer Honda Grogol Kabupaten Sukoharjo 


\section{Uji Hipotesa}

Uji t :

a. Kualitas produk berpengaruh positif dan signifikan terhadap citra merek.

b. Customer relationship management berpengaruh positif dan signifikan terhadap citra merek.

c. Kualitas produk berpengaruh positif dan signifikan terhadap keputusan pembelian.

d. Customer relationship management berpengaruh positif dan signifikan terhadap keputusan pembelian.

e. Citra Merek berpengaruh positif dan signifikan terhadap keputusan pembelian.

\section{Uji F:}

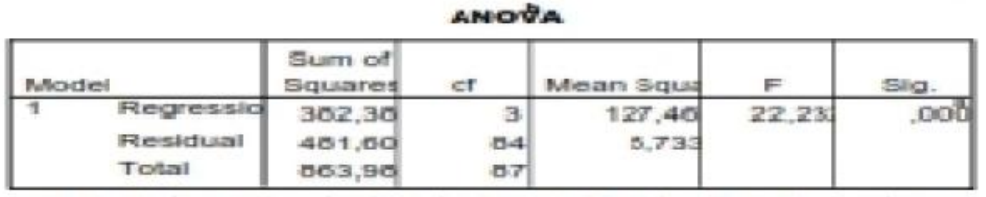

- Prodictars: CConstants, Citra Menek, Kualias Pnoduk, Customer

Managemeint

b. Dependent Varlable: Keputusan Pembelan

Hasil uji secara serempak (Uji $F$ ) pada persamaan kedua diketahui besarnya nilai $\mathrm{F}=22$,232 signifikansi $0,000<0,05$. Sehingga dapat disimpulkan bahwa secara simultan variabel bebas berpengaruh signifikan terhadap keputusan membeli.

\section{Koefisien Determinasi}

Nilai determinasi total sebesar 0,341 , berarti variasi keputusan pembeliandijelaskan oleh kualitas produk dancustomer relationship managementdengan citra merek sebagai variabel intervening sebesar $34,1 \%$, sisanya $65,9 \%$ dijelaskan variabel di luar model, misalnya harga dan lokasi.

\section{Korelasi}

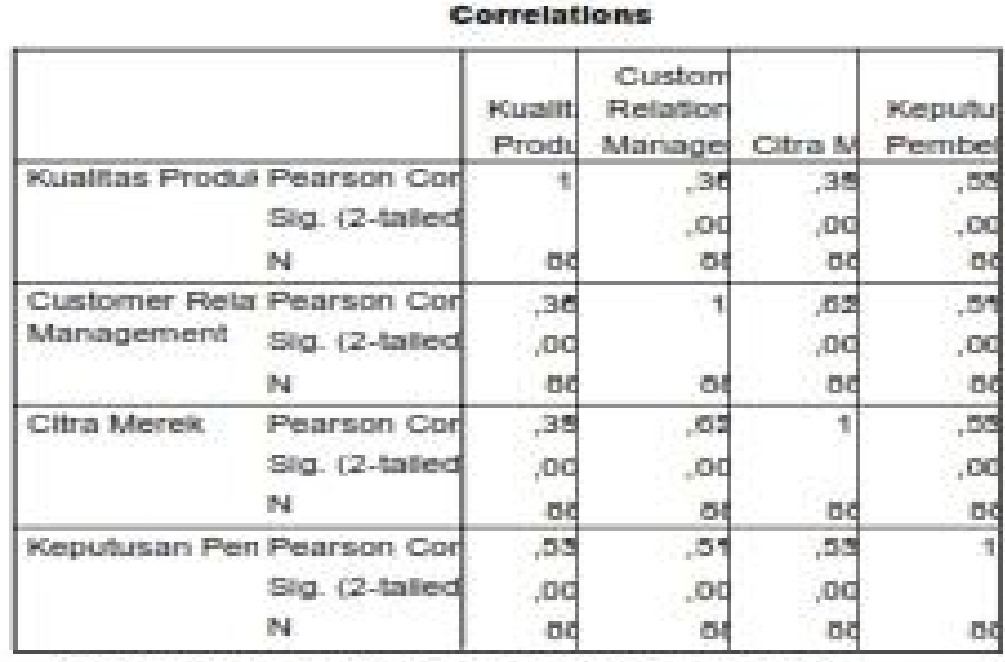

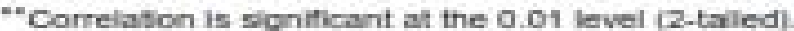

\section{Pengaruh Langsung, Pengaruh Tidak langsung dan Total Pengaruh} Pengaruh Langsung

1) Kualitas produk terhadap keputusan pembelian dengan koefisien sebesar 0,347. 
2) Customer relationship management terhadap keputusan pembelian dengan koefisien sebesar 0,228.

3) Citra merek terhadap keputusan pembelian dengan koefisien sebesar 0,259.

Pengaruh Tidak Langsung

1) Kualitas produk terhadap keputusan pembelianmelalui citra merek dengan koefisien 0,188 x 0,259=0,049.

2) Customer relationship management terhadap keputusan pembelianmelalui citra merek dengan koefisien $0,559 \times 0,259=0,145$.

\section{Total Pengaruh}

1) Kualitas produk terhadap keputusan pembelian ditambah dengan Kualitas produk terhadap keputusan membeli melalui citra merek, $0,347+0,474=0,794$.

2) Customer relationship management terhadap keputusan pembelian ditambah dengan Customer relationship management terhadap keputusan pembelianmelalui citra merek, 0,228 +0,818=1,046.

\section{IMPLIKASI MANAJERIAL}

1. Pengaruh langsung kualitas produk terhadap keputusan pembelian lebih besar dari pada pengaruh tidak langsung Kualitas produk terhadap keputusan pembelian melalui citra merek.

Kotler \& Keller (2009:9) kualitas produk merupakan keseluruhan ciri serta sifat barangan jasa yang berpengaruh pada kemampuan memenuhi kebutuahan yang dinyatakan maupun tersirat. Kualitas produk yang bagus menurut selera konsumen, maka konsumen akan senang dan tertarik untuk melakukan pembelian. Dari hasil penyebaran kuesioner ini, konsumen memutuskan membeli Sepeda Motor Skuter Matic Honda merupakan produk yang paling berkualitas dibandingkan sepeda motor Skuter Matic merek lain, ini merupakan alasan paling banyak di jawab oleh responden tentang keputusan pembelian yang dilakukan. Selain itu, konsumen mengerti manfaat yang diberikan sepeda motor Skuter Matic Honda memberikan kepuasan bagi diri pembeli atau pemiliknya.

Konsumen membeli sepeda motor Skuter Matic Honda karena menyukai modelnya yang cukup banyak dan bagus. Konsumen tertarik membeli sepeda motor Skuter Matic Honda karena memiliki banyak pilihan jenis dan warna yang menarik dan beragam, membeli sepeda motor Skuter matic Honda karena lebih irit bahan bakar dibandingkan merek lain, sepeda motor Skuter Matic Honda dapat diperbaiki di semua bengkel, perawatan yang mudah juga merupakan pilihan membeli. Berbagai alasan konsumen membeli sepeda motor jenis Skuter Matic Honda. Dan ini secara keseluruhan terbuktikan dengan jumlah pembelian Skuter Matic Honda paling tinggi diantara merek-merek yang lain.Yuliana,

2015.http://hargamotor.co.id/review- motor/10-sepeda-motor-matic-terbaik-di indonesia.

2. Customer relationship management terhadap keputusan pembelianlebih besar dari pada pengaruh tidak langsung Customer relationship management terhadap keputusan pembelian melalui citra merek.

CustomerRelationship management adalah suatu proses menciptakan, mempertahankan dan meningkatkan hubungan-hubungan yang kuat dengan para pelanggan dan stakeholder lainnya. Selain merancang strategi baru untuk menarik pelanggan baru dan menciptakan transaksi dengan mereka, perusahaan terus menerus sedang berjuang mati-matian untuk mempertahankan pelanggan yang ada dan membangun relasi jangka panjang yang mampu mendatangkan laba relationship management adalah suatu pengembangan dan pemeliharaan dalam jangka panjang untuk hubungan biaya yang efektif dengan pelanggan secara individu, pemasok, karyawan, dan untuk kerjasama lain yang saling menguntungkan.

Pendekatan yang dilakukan dalam bentuk relationship ini lebih disukai konsumen karena dengan relationship proses pembelian dan memperoleh informasi dapat lebih mudah,resiko dapat dikurangi serta mereka akan memperoleh kenyamanan psikologis. Selain itu,relationship management merupakan senjata yang ampuh meningkatkan relationship quality dan berguna dalam peningkatan kepuasan terhadap pelayanan jasa yang diberikandengan mereka.

Dari hasil penyebaran kuesioner menunjukkan, Dealer Honda ini konsisten dalam menyediakan kualitas 
pelayanan, memberikan informasi yang akurat dan dapatdipercaya,sertamemuaskan. Dealer motor Honda menjaga hubungan terusmenerus denganpelanggan dengan memberikan pelayanan baik dari komunikasi yang baik dan lancar maupun pelayanan service gratis yang diberikan.

3. Hasil total pengaruh dapat diketahui bahwa untuk menaikkan keputusan pembelian lebih efektif melaluiCustomer relationship management.

Kotler (2005:204) mengemukakan bahwa dalam proses pembelian terdapat lima tahapan yang akan dilalui yaitu pengenalan masalah, pencarian informasi, evaluasi alternative, keputusan pembelian, dan perilaku paska pembelian. Setiap konsumen akan melelui ke lima tahap tersebut, namun proses yang dilalui tidaklah sama dan saling berurutan.

Perilaku paska pembelian merupakan faktor penentu bagi pemasar, karena puas atau ketidakpuasan konsumen akan mempengaruhi tingkah laku selanjutnya. Konsumen yang merasa tidak puas dan merasa pengorbanan yang dilakukan tidak sepadan dengan manfaat yang ada dalam produk kemungkinan akan melakukan penghentian pemakaian produk. Begitupun sebaliknya apabila mereka merasa puas maka kesempatan terjadinya pengulangan pembelian akan terbuka lebar.

Berbagai alasan yang dilakukan konsumen mengadakan pembelian Skuter matic Honda, karena sepeda motor Skuter Matic Honda karena menyukainya, memenuhi kebutuhan saya sebagai alat transportrasi sehingga saya memutuskan untuk membelinya, membeli sepeda motor Skuter Matic Honda karena sistem pembayarannya dapat dikredit, konsumen akan selalu menggunakan sepeda motor Skuter Matic Honda.

Customer relationship management yang dilakukan pihak motor Honda menjaga hubungan terus menerus dengan pelanggan, pelayanan sesuai dengan kebutuhan pelanggan ada cash back (pengembalian tunai) pada transaksi pembelian serta informasi yang akurat dan dapat dipercaya,serta memuaskan.

\section{PENUTUP}

\section{Kesimpulan}

1. Dari hasil uji t:

a. Kualitas produk berpengaruh positif dan signifikan terhadap citra merek.

b. Customer relationship management berpengaruh positif dan signifikan terhadap citra merek.

c. Kualitas produk berpengaruh positif dan signifikan terhadap keputusan membeli.

d. Customer relationship management berpengaruh positif dan signifikan terhadap keputusan membeli

e. Citra Merek berpengaruh positif dan signifikan terhadap keputusan membeli.

2. Variabel bebas berpengaruh signifikan terhadap keputusan membeli secara simultan.

3. Variasi keputusan membeli dijelaskan oleh kualitas produk dan customer relationship management dengan citra merek sebagai variabel intervening sebesar $34,1 \%$, sisanya $65,9 \%$ dijelaskan variabel di luar model, misalnya harga, lokasi dan promosi.

4. Kesimpulan analisis jalur :

a. Pengaruh langsung kualitas produk terhadap keputusan membeli lebih besar dari pada pengaruh tidak langsung kualitas produk terhadap keputusan membeli melalui citra merek, maka citra merek tidak efektif sebagai variabel mediasi.

b. Pengaruh langsung customer relationship management terhadap keputusan membeli lebih besar dari pada pengaruh tidak langsung customer relationship management terhadap keputusan membeli melalui citra merek, maka citra merek tidak efektif sebagai variabel mediasi.

c. Dari hasil total pengaruh, untuk menaikkan keputusan pembelian lebih efektif melalui customer relationship management.

\section{Keterbatasan Penelitian}

1. Hasil penelitian ini tidak dapat digeneralisasi pada lokasi yang lain, karena karakteristik obyek dan responden terbatas pada konsumen yang membeli sepeda motor Skuter Matic Honda di Dealer Honda Grogol Sukoharjo.

2. Hasil pengamatan di lapangan bahwa partisipasi responden dalam mengisi kuesioner sangat bervariasi, 
ada yang mengisi dengan serius tetapi ada pula responden yang kurang serius mengisi kuesioner, sehingga hal ini sangat mempengaruhi hasil data.

3. Dalam penelitian ini, peneliti hanya menggunakan variabel kualitas produk, customer relationship management dan citra merek untuk mengukur pengaruhnya terhadap keputusanmembeli.

\section{Saran}

1. Meningkatkan customer relationship management, yaitu dengan cara pihak manajemen untuk selalu inovasi hal-hal yang mendukung CRM, meningkatkan kualitas pelayanan, meningkatkan penyediaan informasi yang akurat dan dapat dipercaya, meningkatkan kepuasan konsumen, meningkatkan hubungan terus menerus dengan pelanggan, meningkatkan penjualan secara kredit.

2. Meningkatkan kualitas produk yaitu dengan cara memperbaiki desain yang memiliki spesifikasi yang inovatif (seperti bagasi yang luas, kunci pengaman, standar otomatis), menambah pilihan warna, meningkatkan keiritan bahan bakar, meningkatkan kemudahan untuk direparasi, meningkatkan penampilan sporty dan mengurangi kecepatan panasnya mesin

\section{DAFTAR PUSTAKA}

Alfred, Owusu. 2013. Influence of Price and Quality On Consumer Purchase of Mobile Phone In The Kumasi Metropolis In Ghana A comparative Study. Marketing department, Kumasi Pholitechnic, Ghana.europan Journal of Business And Management.

Arikunto, Suharsini. 2011. Prosedur Penelitian: Suatu Pendekatan Praktek. Jakarta : Rineka Cipta Asri, Marwan. 2003. Marketing. Jakarta: Erlangga.

Buchari Alma, 2000, Manajemen Pemasaran dan Pemasaran Jasa, Cetakan keempat, Alfabeta, Bandung.

Durianto, Darmadi, dkk. 2001. Startegi menaklukkan Pasar Melalui Riset Ekuitas dan PerilakuMerek. Jakarta: Gramedia Pustaka Utama

Durianto, Darmadi, dkk. 2001. Startegi menaklukkan Pasar Melalui Riset Ekuitas dan PerilakuMerek. Jakarta: Gramedia Pustaka Utama

Evelina, Nela. 2012. Pengaruh citra Merek, Kualitas Produk, Harga, dan Promosi Terhadap Keputusan Pembelian Kartu Perdana Telkomfexi. Diponegoro Journal of Social and Politic. Universitas Diponegoro. Semarang

Gujarati, Damodar. 2013. Basic Econometrics, Fourth Edition. Mc grow Hill. Singapore Hadi. 2011. Metodologi Reserch. Jilid 1.Yogyakarta : Andi Offset http://pertamax7.com/2015/07/15/honda-juara- motor-maticdan-bebek-ms-66-yamaha- juaranya-motor-sport-aisi-semester-1- 2015/. diakses Kamis, 8 oktober 2015.

Kotler, Philip. 2000. Marketing Management, The millennium ed. New jersey: Phipe Prantice Hall.

Kotler, Phillip dan Gary Amstrong. 2001. Prinsip-Prinsip Pemasaran, jilid 2, edisi ke-8, Penerbit Erlangga, Jakarta.

Kotler, Philip. 2002. Manajemen Pemasaran, Analisa perencanaan, Implementasi dan control. Edisi Kesembilan. Jilid 1 dan jilid 2.Jakarta : Prehalindo. alih bahasa oleh Hendra Teguh S.E.,A.K., dan Ronny A. Rusli, S.E.

Kotler, Philip, 2003, Edisi Indonesia, Drs. Benyamin Molan, Manajemen Pemasaran, Edisi Kesebelas, Indeks, Jakarta.

Kotler, Philip. 2005. Manajemen Pemasaran. Edisi ke Sebelas jilid 1.Jakarta : PT indeks Kelompok Gramedia. 
Kotler, Philip dan Garry Amstrong. 2008. Prinsip-Prinsip Pemasaran. Jilid 1.Jakrta : Erlangga.

Kotler, Philip \& Keller, Kevin L. 2009.Manajemen Pemasaran, edisi 13 Jilid I. Erlangga, Jakarta.

Lupiyoadi, Rambat, Hamdani, A.2004. Manajemen Pemasaran Jasa. Jakarta: Salemba Empat.

Kuncoro, Mudrajad. 2013. Metode Kuantitatif Teori dan Aplikasi untuk Bisnis dan Ekonomi.Edisi 1.Yogyakarta ; AM YKPN.

Martin, E.W., Brown, C.V., DeHayes, D.W., Hoffer, J.A., Perkins, W.C., 2005, Customer Relationship Management", Managing Information Technology (5th ed.), Pearson Prentice Hall, pp. 194-196

Mursid, M. 2008. Manajemen Pemasaran. Bumi Aksara. Jakarta.

Oladepo, Onigbinde Isaac. 2015. The Influence of Brand Image and Promotional Mix On consumer Buying Decision- A Study Of beverage Consumers in lagos State, Nigeria.Southwestern University Nigeria. British Journal Of marketing Studies.

Prasetyo, Olvie Okta. 2012. Pengaruh Kualitas Produk, Harga dan Promosi Terhadap Keputusan Pembelian Motor Yamaha Mio, (Studi Kasus Pada PT. Harpindo Jaya Majapahit Semarang). Universitas Diponegoro Semarang. Diponegoro Journal of Social and Politic.

Rangkuti, Fredy. 2002. The Power of Brand: Teknik mengelola brand dan Startegi pengembangan Merek. Jakarta: Gramedia Pustaka Utama.

Santoso, Krestiawan Wibowo. 2013. Pengaruh harga dan Promosi terhadap Keputusan Pembelian Permen Tolak Angin di Semarang. Univesritas Diponegoro. Diponegoro Journal of Social and Politic.

Santoso, Singgili. 2011. Buku Latihan SPSS Statistik parametik. Edisi Pertama. Jakarta : PT Elex Media Komputindo.

Setiadi, Nugroho, 2010. Perilaku Konsumen:Perspektif Kontemporer pada Motif, Tujuan, dan Keinginan Konsumen.Jakarta : Kencana Prenada Media

Sugiyono. 2011. Statistik Untuk Penelitian. Bandung: Alfabeta

Swastha, Basu. 2000. Azas-azas Marketing. Yogyakarta : Liberty.

Tjiptono, Fandy. 2008. Strategi Pemasaran Edisi ke tiga.Andi Offset, Yogyakarta.

Yuli ana, 2015.http://hargamotor.co.id/review- motor/10-sepeda-motor-matic-terbaik-di- indonesia. diakses tanggal 24 oktober 2015 Umar, Husain. 2005. Studi Kelayakan Bisnis, edisi Tiga. Jakarta: PT gramedia Pustaka Utama. 